\title{
IDENTIFIKASI PORTOFOLIO, STRATEGIC SOURCING DAN PENGUKURAN KETERSEDIAAN LAYANAN TI PADA PT PLN (PERSERO) WILAYAH SUMATERA SELATAN, JAMBI, DAN BENGKULU
}

\author{
Herianto $^{1}$ dan Achmad Nizar Hidayanto ${ }^{2}$ \\ ${ }^{1}$ STMIK MDP Palembang, J1. Rajawali No. 14 Palembang, 30113, Indonesia \\ ${ }^{2}$ Fakultas Ilmu Komputer, Universitas Indonesia, Kampus Baru UI Depok, Jawa Barat, 16424, Indonesia \\ E-mail: herianto.kwok@gmail.com
}

\begin{abstract}
Abstrak
PT. PLN Wilayah Sumsel, Jambi dan Bengkulu banyak menggunakan layanan TI agar dapat mengelola proses bisnisnya dengan baik. Tidak adanya suatu mekanisme pengukuran kinerja pihak ketiga membuat perusahaan kesulitan mengukur kinerja pihak ketiga. Penelitian ini ditujukan untuk mengatasi berbagai permasalahan yang ada di PT. PLN Wilayah Sumsel, Jambi dan Bengkulu. Tahap pertama penelitian ini akan dilakukan dengan menjabarkan strategi dengan analisis SWOT, yang menghasilkan portofolio layanan TI. Tahap selanjutnya adalah pemberian rekomendasi mengenai strategic sourcing dalam membangun layanan TI perusahaan dengan menganalisis kondisi perusahaan saat ini. Pada tahap akhir penelitian akan dijabarkan mengenai mekanisme pengukuran ketersediaan layanan TI dengan kerangka kerja COBIT 4.1 sub segmen DS1. Dari hasil penelitian diperoleh portofolio layanan TI yang secara efektif dapat mendukung perusahaan. Penelitian ini juga menghasilkan temuan yang menunjukkan bahwa perusahaan belum mampu mengelola sendiri layanan TI secara internal, sehingga pengembangan layanan TI sebaiknya dilakukan melalui outsourcing. Formulasi mengenai SLA juga diusulkan dalam penelitian ini agar dapat digunakan untuk mengukur kinerja pengelola layanan TI perusahaan.
\end{abstract}

Kata Kunci: analisis SWOT, portofolio layanan TI, COBIT, strategic sourcing, SLA

\begin{abstract}
PT. PLN Region Sumsel, Jambi and Bengkulu use IT services in order to properly manage its business processes. The absence ofa mechanism for third-party performance measurement make it difficult to measure the performance of third parties. This study aimed to address the various problems that exist in there. The first phase of this research will be done by outlining strategies with SWOT analysis, which produces a portfolio of IT services. The next stage is the provision of recommendations on the strategic sourcing in developing IT services in the company by analyzing the current condition of the company. In the final stage of research, we will clarify the mechanisms in measuring the availability of IT services with COBIT 4.1 framework, DS1 sub segments. From the research results obtained a portfolio of IT services that can effectively support the company. The study also produced findings that shows the company has not been able to manage their own IT services internally, so the development of IT services should be done through outsourcing. Formulation of the SLA is also proposed in this study, so that can be used to measure the performance of IT service management company.
\end{abstract}

Keywords: SWOT analysis, portfolio of IT services, COBIT, strategic sourcing, SLA

\section{Pendahuluan}

PT. PLN (Persero) adalah perusahaan nasional yang bergerak di bidang kelistrikan, yang berorientasi dalam menyediakan tenaga listrik bagi setiap masyarakat Indonesia. PT. PLN (Persero) dalam operasionalnya, memonopoli penyaluran dan penjualan tenaga listrik di seluruh wilayah Indonesia. Oleh karena itu, PT. PLN (Persero) memiliki kantor perwakilan di setiap provinsi di seluruh wilayah Indonesia. Selain itu,
PT. PLN (Persero) juga bertanggung jawab penuh dalam hal menyediakan dan menyalurkan tenaga listrik untuk setiap masyarakat Indonesia. Dalam kegiatan operasionalnya, PT. PLN (Persero) bertanggung jawab dalam menyediakan tenaga listrik bagi masyarakat Indonesia.

Sesuai dengan Undang Undang Dasar 1945 pasal 33 ayat 2 yang menyatakan bahwa "Cabangcabang produksi yang penting bagi negara dan yang menguasai hajat hidup orang banyak dikuasai oleh negara", PT. PLN (Persero) 
kemudian ditugaskan untuk menjadi satu-satunya perusahaan yang berhak mengelola tenaga listrik di Indonesia. Dikarenakan PT. PLN (Persero) diberikan hak penuh dalam mengelola tenaga listrik di Indonesia, maka PT. PLN (Persero) memiliki cabang di setiap provinsi di Indonesia, salah satunya di kota Palembang dengan status wilayah dengan nama Wilayah Sumatera Selatan, Jambi, dan Bengkulu (WS2JB).

Namun dalam perjalanannya, PT. PLN (Persero) WS2JB belum menunjukkan kinerja yang baik dalam hal pelayanan bagi pelanggan, dan perusahaan seringkali merugi. Kecenderungan kerugian yang dialami perusahaan membuat perusahaan hanya berkonsentrasi dalam mencapai tingkat penjualan tenaga listrik setinggi-tingginya, sedangkan disisi lain seringmengabaikan faktor kepuasan pelanggan. Kondisi ini juga berdampak pada layanan TI perusahaan yang merupakan tulang punggung proses bisnis perusahaan. Perusahaan mengeluarkan dana yang cukup besar untuk membiayai layanan TI yang secara khusus dihitung dari banyaknya lembar rekening terjual, namun disisi lain tidak banyak berinvestasi pada layanan-layanan TI yang bersifat melayani pelanggan.

Permasalahan lainnya dapat dilihat dari banyaknya aplikasi-aplikasi yang ada di lingkungan PT. PLN (Persero) WS2JB yang dibangun oleh berbagai macam vendor dan tidak terintegrasi dengan baik. Layanan-layanan TI tersebut lebih banyak berkonsentrasi pada bagaimana perusahaan dapat mencapai target pemasukan sebesar-besarnya. Untuk itu, diperlukan suatu portofolio layanan-layanan TI supaya perusahaan dapat mencapai tujuan yang terdapat pada visi misi perusahaan dan pengadaan layanan TI dapat berjalan efektif.

Aplikasi yang ada saat ini yang tidak terintegrasi dan dibangun oleh pihak ketiga (outsourcing) membuat perusahaan sangat bergantung dengan vendor. Perlu adanya suatu proses analisis apakah memang dibutuhkan pihak ketiga dalam membangun layanan TI, supaya pengembangan layanan TI dapat efektif dan efisien. Tidak adanya mekanisme yang mengatur dan menilai ketersediaan aplikasi-aplikasi menyebabkan perusahaan tidak dapat menilai kinerja pihak ketiga secara lebih dalam. Dalam hal ini, dibutuhkan suatu model perhitungan untuk mengukur kinerja pengembang sebagai dasar bagi perusahaan untuk memberikan penghargaan atau sanksi.

\section{Metodologi}

Penelitian ini merupakan penelitian yang terkait dengan perancangan Service Level Agreement (SLA) seperti yang dilakukan oleh [1][2]. Selain itu dalam penelitian ini juga akan diulas mengenai pemilihan strategi sourcing yang sesuai untuk PT. PLN (Persero) WS2JB. Penelitian terkait dengan strategi untuk sourcing bisa dilihat di [3]. Penelitian ini juga terkait erat dengan Tata Kelola TI.

Perbandingan berbagai kerangka Tata Kelola TI bisa ditemukan di [4]. Adapun yang dipakai sebagai acuan dalam penelitian ini adalah kerangka kerja COBIT, yang juga digunakan oleh [5][6]. SWOT analysis [7] adalah sebuah tool yang sangat penting untuk mengaudit posisi strategis secara keseluruhan dari sebuah bisnis (perusahaan) dan lingkungannya. SWOT analysis dibagi menjadi dua bagian yaitu analisis internal perusahaan yang terdiri dari analisis strengths dan weaknesses, dan analisis lingkungan eksternal yang terdiri dari analisis opportunities dan threats (gambar 1). Metode analisis SWOT bisa digunakan untuk menganalisis strategi-strategi apa saja yang dapat dilakukan oleh perusahaan, karena metode ini memandang sebuah strategi dari dua sisi yaitu eksternal dan internal. Oleh karena itu, hasil dari analisis ini merupakan kombinasi dari strategi-strategi yang dapat menguatkan perusahaan baik dari dalam maupun luar.

Model analisis strategic grid for information resource management (gambar 2) merupakan suatu tabel yang menunjukkan posisi strategis perusahaan untuk melakukan outsourcing [8]. Perusahaan yang berada pada kuadran support, maka outsourcing disarankan untuk dilakukan terutama pada perusahaan besar. Bagi perusahaan yang berada pada kuadran factory, juga disarankan untuk melakukan outsourcing, kecuali perusahaan memiliki pengelolaan internal TI yang baik. Untuk perusahaan yang berada pada kuadran turn around, disarankan outsourcing dilakukan secara mixed. Bagi perusahaan yang berada pada kuadran strategic, juga disarankan outsourcing dilakukan secara mixed.

Kerangka kerja COBIT [9] menyediakan referensi model proses dalam mengelola aktivitas TI. Proses pengumpulan model operasional untuk semua bagian dalam organisasi yang terkait dengan TI adalah langkah awal dan yang paling penting dalam mencapai pengelolaan yang baik. COBIT juga menyediakan kerangka kerja untuk mengukur dan mengawasi performa TI. Dalam penelitian ini, COBIT yang digunakan adalah COBIT 4.1. 


\begin{tabular}{|c|c|c|}
\hline $\begin{array}{c}\text { Internal } \\
\text { Factors } \\
\text { Factors }\end{array}$ & $\begin{array}{c}\text { Strengths } \\
\text { (S) }\end{array}$ & $\begin{array}{c}\text { Weaknesses } \\
\text { (W) }\end{array}$ \\
\hline $\begin{array}{c}\text { Oportunities } \\
\text { (O) }\end{array}$ & $\begin{array}{c}\text { Strategi yang menggunakan } \\
\text { kekuatan untuk } \\
\text { memanfaatkan peluang } \\
\text { (SO) }\end{array}$ & $\begin{array}{c}\text { Strategi yang meminimalkan } \\
\text { kelemahan untuk } \\
\text { mendapatkan peluang } \\
\text { (WO) }\end{array}$ \\
\hline $\begin{array}{c}\text { Threats } \\
\text { (T) }\end{array}$ & $\begin{array}{c}\text { Strategi yang menggunakan } \\
\text { kekuatan untuk } \\
\text { menghindari ancaman } \\
\text { (ST) }\end{array}$ & $\begin{array}{c}\text { Strategi untuk } \\
\text { meminimalkan kelemanan } \\
\text { dan menghindari ancaman } \\
\text { (WT) }\end{array}$ \\
\hline
\end{tabular}

Gambar 1. SWOT analysis [7].

COBIT 4.1 mengelompokkan aktivitas TI ke dalam model proses umum yang terbagi menjadi empat domain, yaitu pertama plan and organize yang menyediakan arahan untuk penyampaian solusi dan service. Kedua acquire and implement yang menyediakan solusi-solusi dan mengimplementasikan solusi-solusi tersebut supaya dapat masuk menjadi layanan. Ketiga deliver and support yang menerima solusi-solusi dan menjadikan solusi-solusi tersebut berguna bagi pengguna. Keempat monitor and evaluate yang mengawasi seluruh proses untuk memastikan arahan yang disediakan dapat diikuti.

\section{Hasil dan Pembahasan}

Dalam penelitian ini, analisis SWOT diterapkan untuk menganalisis kondisi internal dan eksternal perusahaan agar diperoleh strategistrategi apa saja yang dapat dilakukan oleh perusahaan. Oleh karena itu, hasil dari analisis ini merupakan kombinasi dari strategi-strategi yang dapat memperkuat perusahaan baik dari dalam maupun luar. Strategi yang pertama yaitu strengths identification terdiri dari: listrik merupakan kebutuhan pokok masyarakat, tenaga listrik yang dijual perusahaan lebih murah, memiliki jumlah pelanggan yang relatif akan terus bertambah, manajemen memiliki kepedulian yang tinggi terhadap TI, dan memiliki kantor perwakilan hampir di setiap wilayah kota dan kabupaten.

Strategi yang kedua yaitu weaknesses identification terdiri dari: PT. PLN (Persero) WS2JB terlalu banyak melibatkan pihak ketiga dalam melakukan proses bisnisnya, tidak adanya rekrutmen profesional, kurangnya fasilitas perusahaan khususnya loket penagihan, keputusan penentuan Tarif Dasar Listrik tidak diserahkan secara penuh pada manajemen perusahaan, dan kurangnya tenaga TI yang dimiliki oleh perusahaan.
Strategi yang ketiga yaitu opportunities identificationterdiri dari: prospek pelanggan yang sangat besar, pertumbuhan ekonomi yang semakin meningkat, perkembangan teknologi yang sangat cepat, dan tidak adanya pesaing. Strategi yang keempat yaitu threats identification terdiri dari: infrastruktur TI yang sudah tertinggal, banyaknya pencurian tenaga listrik yang belum ditangani dengan baik, kerusakan pada pembangkit listrik, dan peraturan pemerintah yang merugikan perusahaan. Setelah mendefinisikan komponenkomponen dari analisis SWOT, yaitu strengths, weaknesses, opportunities, dan threats, maka selanjutnya komponen-komponen tersebut dikombinasikan untuk menciptakan strategistrategi bisnis bagi perusahaan dalam meningkatkan kinerjanya. Analisis tersebut digambarkan dalam kombinasi antara strength opportunities, strength threats, weaknesses opportunities, dan weaknesses threats. Setelah mendapatkan serangkaian strategi bisnis, strategi tersebut kemudian dijabarkan kembali untuk mendapatkan kebutuhan layanan TI yang dapat dibangun untuk mendukung strategi bisnis yang telah dijabarkan sebelumnya.

Strategi strengths opportunities yang pertama yaitu percepatan pelayanan yang lebih baik dan mudah, serta memberikan waktu lifecycle yang lebih pendek untuk permohonan mutasi pelanggan. Kebutuhan layanan TI terdiri dari Online Customer Information System modul fungsi I, SMS gateway, dan Web Based Customer Information System. Strategi yang kedua yaitu melakukan investasi yang menunjang peningkatan penyediaan daya listrik ke daerah. Kebutuhan layanan TI ini terdiri dari: Online Customer Information System modul fungsi I, $E$ Procurement, dan Enterprise Resource Planner. Strategi yang kedua yaitu menyediakan payment point di setiap kantor perwakilan. Kebutuhan layanan TI ini terdiri dari:Online Customer Information System modul fungsi $\mathrm{V}$ dan Host to Host Payment System. 


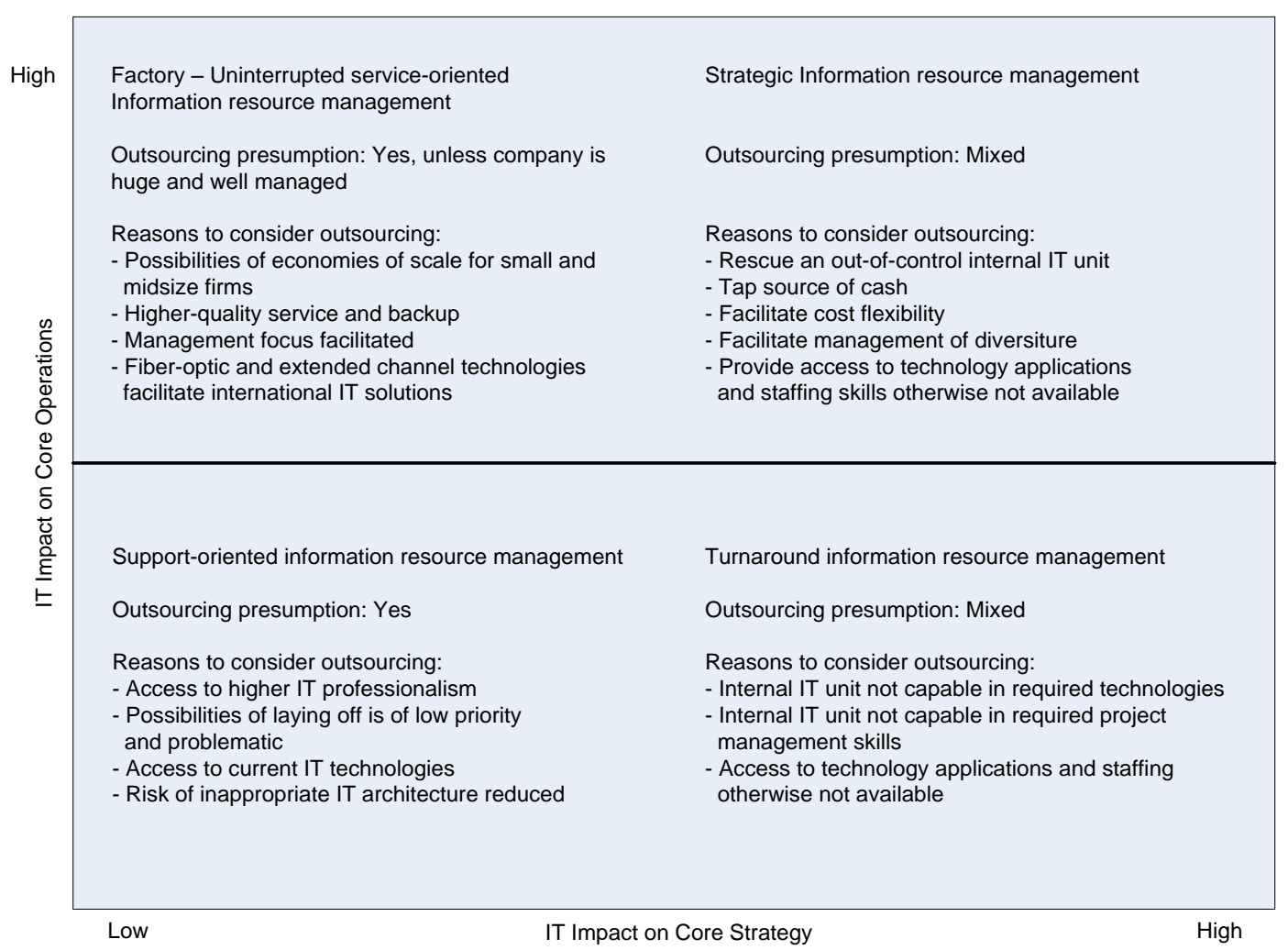

Gambar 2. Strategic grid for information resource management [8].

Strategi strengths threats memiliki beberapa strategi antara lain yang pertama melakukan pengadaan infrastruktur TI secara berkala dan terencana dengan kebutuhan layanan TI yaitu $E$ Procurement, Online Customer Information System modul fungsi I, dan Office Application. Strategi yang kedua yaitu meningkatkan intensitas operasi penertiban pencurian tenaga listrik dengan kebutuhan layanan TI antara lain, Online Customer Information System modul fungsi I dan Geographical Information System. Strategi ketiga yaitu mempertegas sanksi terhadap pencurian. Kebutuhan layanan TI Online Customer Information System modul fungsi I.

Strategi weaknesses opportunities memiliki beberapa strategi, antara lain: pertama, melakukan outsourcing TI dengan kebutuhan layanan TI yaitu, Help desk, Online Customer Information System modul fungsi I, Web Based Customer Information System, Call Center dan SMS Gateway. Kedua, merekrut tenaga profesional TI untuk membangun sistem dan mengelola data dengan kebutuhan layanan TI antara lain, Online Customer Information System, Help desk, Aplikasi Pengendalian Dokumen, Aplikasi Monitoring Tugas. Strategi ketiga yaitu membentuk suatu divisi yang secara khusus mengambil alih proses bisnis pihak ketiga dengan kebutuhan layanan TI
Online Customer Information System modul fungsi I.

Strategi weaknesses threats memiliki beberapa strategi antara lain yang pertama membuka suatu wadah untuk menampung keluhan pelanggan terhadap kinerja pihak ketiga dengan kebutuhan layanan TI antara lain, Call Center, Help desk System, Web Based Customer Information System, E-mail, dan Mailing List. Strategi yang kedua yaitu memberikan kualitas pelayanan yang lebih baik dan ramah kepada pelanggan dengan kebutuhan layanan TI antara lain, Call Center, Customer Relationship Management, dan Help desk. Ketiga, menggunakan alat ukur yang lebih baik untuk mendeteksi pencurian dengan kebutuhan layanan TI, antara lain: Geographical Information System dan Automatic Meter Reading.

Hasil perumusan strategi bisnis dan layanan TI tersebut kemudian dipetakan kembali ke setiap divisi di dalam perusahaan, supaya kebutuhan layanan TI dapat mendukung setiap divisi dalam proses bisnis. Hasil pemetaan layanan TI ke setiap divisi yakni layanan TI Fungsi I Pelayanan Pelanggan yang terdiri dari Online Customer Information System modul fungsi I, Web Based Customer Information System, Call Center, Customer Relationship Management, SMS 
Gateway, E-Procurement, dan Office Application. Layanan TI Fungsi II Pembacaan Meter yang terdiri Automatic Meter Reading dan Online Customer Information System modul Fungsi II. Layanan TI Fungsi III Sistem Pembuatan Rekening Listrik dan Fungsi IV Pembukuan terdiri dari Online Customer Information System modul Fungsi III dan Online Customer Information System modul Fungsi IV.

Layanan TI Fungsi V Penagihan terdiri dari Online Customer Information System modul Fungsi V, Host to Host Payment System dan SMS Gateway. Layanan TI Fungsi VI Pengawasan Kredit terdiri dari Geographical Information System, Online Customer Information System modul Fungsi VI, dan Automatic Meter Reading. Layanan TI Bagian Sistem Informasi terdiri dari Enterprise Resource Planner, Email, Mailing List, Aplikasi Pengendalian Dokumen, Aplikasi Monitoring Tugas, Help desk, dan Office Application. Layanan TI yang telah diidentifikasi melalui analisis SWOT kemudian dipetakan kedalam portofolio yang dapat dilihat pada gambar 3 .

Untuk menentukan sourcing layanan TI perusahaan, maka perlu diketahui kondisi existing Unit TI Internal Perusahaan. Beberapa hal yang menjadi bahan pertimbangan untuk melakukan strategic sourcing yaitu, pembiayaan SDM pengelola layanan TI, pengadaan perangkat TI, biaya lisensi software, tugas dan tanggung jawab. Pembiayaan SDM pengelola layanan TI, yaitu biaya yang dibutuhkan perusahaan untuk melakukan sourcing layanan TI, baik insource maupun outsource relatif sama. Apabila perusahaan lebih memilih untuk mempekerjakan tenaga TI internal, artinya perusahaan harus menanggung biaya yang cukup besar untuk pemberian gaji, tunjangan, dan lain sebagainya selama tenaga TI tersebut menjadi karyawan perusahaan, Kompetensi SDM unit TI internal, Pengembangan Unit TI internal.

Pada pengadaan perangkat TI, perusahaan relatif lebih memilih untuk menyewa perangkat TI secara khusus untuk pengadaan hardware. Hal ini memungkinkan perusahaan mendapatkan teknologi terkini dari vendor dan melepaskan biaya pemeliharaan perangkat. Dengan adanya teknologi terbaru, diharapkan performa layanan TI perusahaan dapat semakin meningkat.

Pada biaya lisensi software, perusahaan telah memiliki lisensi software yang dibeli secara khusus oleh kantor pusat sebagai lisensi korporat perusahaan. Untuk itu, setiap kantor perwakilan di daerah dapat menggunakan software resmi tanpa perlu mengeluarkan biaya tambahan untuk mengadakan software.

\begin{tabular}{|c|c|}
\hline $\begin{array}{l}\text { Kuadran Support } \\
\checkmark \text { Office Applicotion (sudah ada) } \\
\checkmark \text { sMS Gotewoy (pengembangan) } \\
\checkmark \text { Aplikasi Pengendalian dokumen (sudah ada) } \\
\checkmark \text { Aplikasi Monitoring Tugas (sudah ada) } \\
\checkmark \text { Emoil (sudah ada) } \\
\checkmark \text { Moiling list (sudah ada) }\end{array}$ & 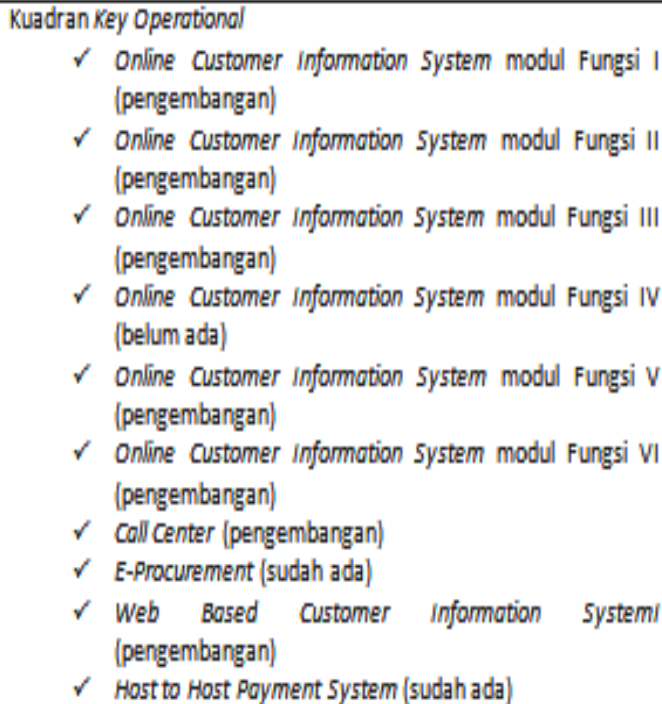 \\
\hline $\begin{array}{l}\text { Kuadran Strotegic } \\
\quad \checkmark \text { Geographical Informotion System (pengembangan) }\end{array}$ & $\begin{array}{l}\text { Kuadran High Potentiol } \\
\quad \checkmark \text { Customer Relotionship Monogement (belum ada) } \\
\checkmark \text { Automatic Meter Reoding (pengembangan) } \\
\checkmark \text { Enterprise Resource Planner (belum ada) } \\
\end{array}$ \\
\hline
\end{tabular}


Pada tugas dan tanggung jawab, Unit TI internal secara khusus memang diarahkan untuk berpikir dan bekerja di level strategis, namun dapat pula bekerja di level operasional. Dahulu, perusahaan cenderung untuk melakukan insource, maka dari itu setiap karyawan yang memiliki keahlian teknis di bidang operasional dimasukkan ke dalam bagian sistem informasi. Saat ini, perusahaan cenderung untuk melakukan outsoucing untuk level operasional, dan menyerahkan kontrol terhadap operasional kepada karyawan. Hal ini dilakukan karena perusahaan terlalu banyak menerima karyawan setingkat D1 untuk kegiatan operasional. Umumnya karyawan setingkat D1 tidak dapat berpikir strategis, memiliki kemampuan TI yang cenderung kurang, dan bekerja di level operasional. Karyawan setingkat D1 juga umumnya kurang memiliki kemampuan untuk mengembangkan diri sehingga menjadi beban perusahaan karena harus menanggung biaya gaji dan tunjangan mereka selama mereka bekerja (gambar 4).

Kompetensi SDM unit TI internal di mana saat ini perusahaan belum memiliki SDM TI internal yang cukup mampu mengembangkan dan mengelola layanan TI. Perusahaan harus membiayai SDM TI internal untuk dapat mengelola sendiri layanan TI perusahaan. Secara khusus untuk karyawan akan diberikan pelatihan di level strategis. Untuk itu, dibandingkan perusahaan harus mengeluarkan biaya yang cukup besar untuk membayar karyawan yang berada di level operasional, perusahaan cenderung untuk memberikan pekerjaan operasional ke outsourcing. Hal ini juga membuat perusahaan dapat menghemat biaya pelatihan yang dibutuhkan karyawan di level operasional.

Pengembangan unit TI internal di mana unit TI internal tidak mengalami permasalahan untuk pengembangan pengetahuan TI apabila dilakukan outsourcing. Pelatihan untuk unit TI internal akan lebih difokuskan di level strategis, sehingga pengetahuan mengenai TI akan lebih dikembangkan di level strategis dan bukan di level operasional. Hal ini berakibat unit TI internal existing tidak mampu membangun dan mengelola layanan TI.

Setelah diketahui kondisi existing unit TI internal perusahaan, maka penulis melakukan analisis rekomendasi strategic sourcing. Tahap pertama yang dilakukan adalah untuk menganalisis faktor-faktor bisnis yang berhubungan dengan keputusan untuk melakukan outsourcing.

Terdapat dua cara pandang kontribusi bisnis yang berbeda untuk dipertimbangkan dalam menentukannya, yaitu posisi kompetitif dan operasi bisnis. Posisi kompetitif dilihat dengan mempertimbangkan kontribusi yang dibuat oleh aktivitas TI, apakah sebagai differensiator atau sebagai komoditas. Suatu aktivitas TI akan menjadi komoditas apabila tidak diharapkan untuk dapat membedakan kemampuan bisnis dari kompetitor, sedangkan differensiator adalah aktivitas TI yang diharapkan dapat menyediakan kemampuan bisnis untuk mencapai competitive advantage. Cara pandang yang kedua adalah operasi bisnis yang dianalisis dengan menentukan apakah aktivitas TI tersebut berguna atau kritis [7].

Setelah melalui proses analisisbusiness factor, maka aplikasi yang terdapat pada kuadran strategic disarankan untuk dilakukan secara internal (insource), sedangkan untuk aplikasi yang terdapat pada kuadran support disarankan untuk dilakukan oleh pihak ketiga (outsourcing). Sedangkan untuk layanan TI lainnya yang terdapat pada kuadran Key Operational dan High Potential lebih disarankan untuk dilakukan oleh pihak ketiga.

Gambaran strategic sourcing tersebut diberikan dengan pertimbangan bahwa unit TI internal existing tidak mampu mengembangkan dan memelihara layanan TI perusahaan. Pertimbangan lain adalah perusahaan saat ini memang cenderung untuk melakukan outsourcing untuk memenuhi kebutuhan operasional perusahaan, dan menyiapkan unit TI internal untuk dapat berpikir strategis bagi perusahaan.

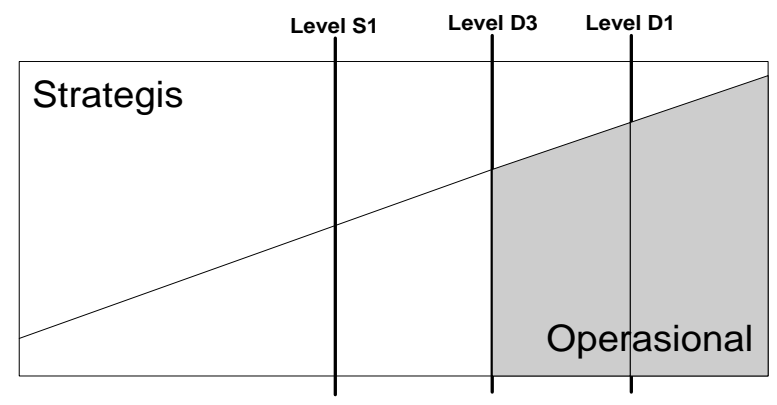

Gambar 4. Area sourcing layanan TI. 
Namun untuk rekomendasi di masa yang akan datang, perusahaan perlu mengadakan langkah-langkah strategis guna menyiapkan unit TI internal untuk dapat mengelola sendiri layanan TI perusahaan, secara khusus untuk setiap layanan TI existing yang dikelola oleh outsourcer. Layanan-layanan TI yang dipakai perusahaan akan lebih baik dikelola secara insourcing supaya keamanan data dapat dijamin oleh perusahaan.

Langkah-langkah tersebut dapat berupa pelatihan-pelatihan yang dilakukan untuk unit TI internal perusahaan, atau dapat juga melengkapi unit TI internal dengan merekrut tenaga profesional. Dengan demikian, perusahaan dapat mencapai visi perusahaan untuk menjadi perusahaan kelas dunia yang bertumbuh kembang dengan mendayagunakan tenaga TI internal.

Setelah melalui proses analisis rekomendasi strategic sourcing, maka selanjutnya akan ditentukan ekspektasi perusahaan dalam menentukan tingkat layanan minimum setiap layanan TI. Ekspektasi performa layanan TI adalah harapan dari perusahaan untuk tingkat ketersediaan layanan TI perusahaan. Pemisahan ekspektasi tingkat layanan TI diklasifikasikan berdasarkan kuadran pada portofolio aplikasi layanan TI yang sudah dijelaskan sebelumnya.

Layanan TI di kuadran key operational diberikan $99 \%$ untuk persentase ketersediaan karena perusahaan menganggap bahwa layanan TI pada kuadran ini penting untuk kelangsungan proses bisnis perusahaan, namun tidak mengesampingkan kemungkinan gangguan yang terjadi. Layanan TI pada kuadran support diberi persentase sebesar 95\% karena cukup mendukung perusahaan dalam melakukan proses bisnisnya. Sedangkan untuk kuadran strategic dan high potential diberikan persentase sebesar $70 \%$ dan 75\% karena belum terlalu berpengaruh pada perusahaan.

Sebelum melakukan perhitungan SLA, perlu ditentukan terlebih dahulu definisi layanan yang akan dihitung dalam SLA seperti, layanan waktu tanggap (Response Time) yang didefinisikan sebagai usaha untuk mencapai waktu ketersediaan terbaik dari perlengkapan netware dan hardware pendukung sistem. Jenis layanan ini digunakan untuk mendapatkan gambaran keberhasilan kinerja waktu tanggap dengan membandingkan persentase jumlah keberhasilan sistem dengan jumlah waktu sistem yang tersedia. Layanan waktu tanggap netware adalah waktu ketersediaan layanan jaringan baik secara fisik maupun nonfisik, sedangkan layanan waktu tanggap hardware adalah waktu ketersediaan layanan perangkat keras non-netware.
Definisi layanan selanjutnya yaitu layanan help desk. Layanan help desk adalah suatu dukungan dalam bentuk pemberian bantuan layanan untuk pemeliharaan infrastruktur selain netware dan hardware. Help desk dapat berupa waktu yang dipakai oleh pengembangdalam memerbaiki aplikasi, atau waktu yang digunakan untuk memperbaiki database apabila terjadi kerusakan. Penentuan persentase tingkat layanan untuk masing-masing layanan adalah sebagai berikut:

TABEL I

PERSENTASE TINGKAT LAYANAN

\begin{tabular}{ll}
\hline \hline Layanan & Persentase \\
\hline Layanan waktu tanggap netware & $40 \%$ \\
Layanan waktu tanggap hardware & $40 \%$ \\
Help desk & $20 \%$ \\
Total & $100 \%$ \\
\hline \hline
\end{tabular}

Persentase yang ditetapkan dengan komposisi di atas didasarkan atas prediksi prioritas layanan yang dibutuhkan oleh perusahaan. Mengingat kebutuhan akan layanan TI perusahaan dalam mencapai penghasilan sangat besar, maka dibutuhkan infrastruktur yang menjamin downtime seminimal mungkin. Untuk itu, diperlukan infrastruktur netware dan hardware yang sangat memadai untuk menekan tingkat downtime, yang dapat menyebabkan persentase tingkat layanan netware dan hardware dibuat lebih tinggi.

Perhitungan layanan waktu tanggap dilakukan dengan rumus sebagai berikut:

$\mathrm{WTH}=\mathrm{HW}$ tersedia $-\Sigma($ ketersediaan HW $) \times 100$ $\%$

Hardware tersedia

$\mathrm{WTN}=\mathrm{NW}$ tersedia $-\Sigma($ ketersediaan NW $) \mathrm{x}$ $100 \%$

Netware tersedia

Netware tersedia

Hardware/netware tersedia merupakan hasil dari perkalian antara jumlah hari dalam satu bulan dikalikan dengan 24 jam, sedangkan ketidaktersediaan hardware/netware adalah jumlah total lama gangguan hardware/netware dalam satu bulan, di mana masing-masing ketidaktersediaan dikali dengan angka indeks unit ketidaktersediaan.

Angka indeks unit ketidaktersediaan didapat dari hasil pembagian jumlah unit terganggu dengan jumlah total unit setingkat rayon/ranting. Hasil perhitungan ketersediaan waktu tanggap kemudian dipetakan ke dalam tabel indeks. persentase layanan seperti terlihat pada tabel II. 
Layanan waktu tanggap diharuskan sedapat mungkin mencapai $100 \%$ dengan indeks layanan yang mencapai angka 1 . Contoh perhitungan layanan waktu tanggap yaitu pada tanggal 10 januari terjadi gangguan di 30 unit dari total 37 unit setingkat rayon/ranting. Lama waktu total gangguan hardware selama 10.5 jam, dan gangguan netware total selama 8.2 jam.

TABEL II

\begin{tabular}{|c|c|c|}
\hline \multicolumn{2}{|c|}{ Persentase layanan } & \multirow{2}{*}{$\begin{array}{l}\text { Angka } \\
\text { indeks }\end{array}$} \\
\hline$<=$ & $>$ & \\
\hline 100 & 99 & 1,00 \\
\hline 99 & 98 & 0,99 \\
\hline 98 & 97 & 0,98 \\
\hline 97 & 96 & 0,96 \\
\hline 96 & 94 & 0,95 \\
\hline 94 & 92 & 0,94 \\
\hline 92 & 90 & 0,93 \\
\hline 90 & 88 & 0,92 \\
\hline 88 & 86 & 0,91 \\
\hline 86 & 84 & 0,90 \\
\hline 84 & 82 & 0,89 \\
\hline 82 & 80 & 0,88 \\
\hline 80 & 78 & 0,87 \\
\hline 78 & 50 & 0,86 \\
\hline 50 & 0 & 0 \\
\hline
\end{tabular}

Maka perhitungan untuk layanan waktu tanggap adalah sebagai berikut:

Layanan ketersediaan hardware bulan Januari = $(((24$ jam x 31 hari $)-(10,5$ jam * 30/37))/(24 jam $\mathrm{x} 31$ hari) $\mathrm{x} 100 \%)$

$((744 \mathrm{jam}-(10,5 \mathrm{jam} * 0,81)) / 744) * 100 \%$

$((744 \mathrm{jam}-8,51) / 744) * 100 \%$

$(735,49 / 744) \times 100 \%$

98,86\% dengan angka indeks 0,99

Layanan ketersediaan netware bulan Januari $=$ $(((24$ jam * 31 hari $)-(8,2$ jam * 30/37))/(24 jam * 31 hari) $\mathrm{x} 100 \%)$

$((744 \mathrm{jam}-(8,2 \mathrm{jam} * 0,81)) / 744) * 100 \%$

$((744 \mathrm{jam}-6,64) / 744) * 100 \%$

$(737,36 / 744) * 100 \%$

$99,11 \%$ dengan angka indeks 1

Perhitungan layanan help desk dilakukan dengan rumus sebagai berikut:

$$
\mathrm{HD}=\begin{gathered}
\begin{array}{c}
\Sigma(\Sigma(\text { Jumlah lama waktu } \\
\text { gangguan / indeks lama } \\
\text { penanganan gangguan hari } \\
\text { kerja atau libur }))
\end{array} \\
\frac{\text { Jumlah laporan gangguan }}{\text { Jumlan }}
\end{gathered}
$$

Jumlah lama waktu gangguan adalah jumlah total lama gangguan yang dialami selama satu bulan, di mana masing-masing lama gangguan dikali dengan angka indeks unit yang mengalami gangguan. Angka indeks unit yang mengalami gangguan didapat dari hasil pembagian jumlah unit terganggu dengan jumlah total unit setingkat rayon/ranting.

Indeks lama penanganan gangguan adalah lama maksimal penanganan gangguan di hari kerja atau di hari libur. Indeks lama penanganan gangguan bernilai 2 jam untuk hari kerja, dan bernilai 4 jam untuk hari libur. Jumlah laporan gangguan adalah jumlah total laporan yang diterima selama satu bulan oleh help desk. Hasil perhitungan help desk kemudian dipetakan ke dalam tabel indeks persentase layanan seperti terlihat pada tabel III.

TABEL III

\begin{tabular}{ccc}
\multicolumn{3}{c}{ INDEKS PERSENTASE LAYANAN HELP DESK } \\
\hline \hline \multicolumn{2}{c}{ Persentase layanan } & \\
\cline { 1 - 2 }$>=$ & $<$ & Angka indeks \\
\hline 0 & 75 & 1,00 \\
75 & 85 & 0,99 \\
85 & 90 & 0,98 \\
90 & 95 & 0,97 \\
95 & 100 & 0,96 \\
100 & 105 & 0,95 \\
105 & 110 & 0,94 \\
110 & 115 & 0,93 \\
115 & 120 & 0,92 \\
120 & 125 & 0,91 \\
125 & 130 & 0,90 \\
130 & 135 & 0,89 \\
135 & 140 & 0,88 \\
140 & 145 & 0,87 \\
145 & 150 & 0,86 \\
150 & & 0,85 \\
\hline \hline
\end{tabular}

Contoh perhitungan layanan help desk yaitu pada bulan januari di hari kerja terjadi dua kali laporan gangguan di 31 unit dari total 37 unit setingkat rayon/ranting. Lama waktu total gangguan di hari kerja 3.8 jam, dan lama waktu total gangguan di hari libur 2.5 jam. Maka perhitungan untuk layanan waktu tanggap adalah sebagai berikut:

Layanan help desk bulan Januari =

$(($ ( 3.8 jam x 31/37)/2 jam $)+($ (2.5 jam $x$ $31 / 37) / 4) / 2$ laporan ) x 100\%

$(((38$ jam $x$ 0.84) $/ 2 \mathrm{jam})+((2.5 \mathrm{jam} \times 0.84) / 4) /$ 2 laporan ) x $100 \%$ 
$((3.19 / 2$ jam $)+(2.1 / 4$ jam $) / 2$ laporan $) \mathrm{x}$ $100 \%$

$((1,60+0,5) / 2$ laporan $) \times 100 \%$

(2.1 / 2 laporan) x $100 \%$

$1.05 \times 100 \%$

$105 \%$ dengan angka indeks 0.95

Perhitungan angka indeks layanan bulanan dilakukan dengan rumus sebagai berikut:

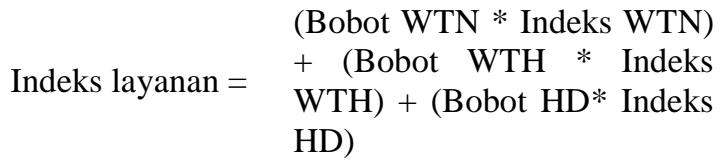

WTN = Waktu tanggap netware

WTH = Waktu tanggap hardware

$\mathrm{HD}=$ Help desk

Contoh perhitungan angka indeks layanan, bobot waktu tanggap netware $=40 \%$, Bobot waktu tanggap hardware $=40 \%$, dan bobot help desk $=20 \%$

Indeks waktu tanggap bulan Januari $=$

$(40 \% * 0,99)+(40 \% * 1)+(20 \% * 0,99)$

$39.6 \%+40 \%+19.8$

$99.4 \%$

\section{Kesimpulan}

Dari penelitian yang sudah penulis lakukan, terlihat bahwa kondisi existing PT. PLN (Persero) WS2JB belum memungkinkan perusahaan untuk dapat mengembangkan dan mengelola sendiri layanan TI. Oleh sebab itu, perusahaan disarankan untuk melakukan outsourcing dalam pengelolaan aplikasi kecuali untuk aplikasi yang berada di kuadran strategic.

Penelitian ini juga telah mendefinisikan SLA untuk layanan TI supaya setiap divisi mampu beroperasi dengan baik sesuai dengan visi misi perusahaan. Melalui pendefinisian SLA ini diharapkan perusahaan dapat mengukur kinerja layanan TI dan juga semua outsourcer yang sudah disewa oleh perusahaan.

\section{Penghargaan}

Terima kasih kepada kedua orang tua dan saudara penulis atas dukungan kepada penulis dalam mengikuti program Pasca Sarjana. Terima kasih kepada manajemen STMIK MDP yang memberikan kesempatan bagi penulis dalam mengikuti program pasca sarjana Universitas Indonesia. Terima kasih kepada Bapak Dr. Achmad Nizar Hidayanto sebagai pembimbing dalam penelitian ini. Terima kasih kepada peserta kuliah Dual-Mode Universitas Indonesia di STMIK MDP atas segala bentuk sharing materi maupun informasi yang berharga bagi terselesaikannya penelitian ini.

\section{Referensi}

[1] G. Ahmed, "Formulasi Service Level Agreement dalam Penyelenggaraan TI: Sebuah Studi Kasus Instansi Pemerintah," Ph.D Thesis, Faculty of Computer Science, Universitas Indonesia, Indonesia, 2005.

[2] F. Santoso, "Perancangan Kerangka Service Level Agreement dalam Penyelenggaraan TI pada Aplikasi Korporat Global Purchase Order: Studi Kasus Perusahaan XYZ Manufaktur Sepatu," Ph.D Thesis, Faculty of Computer Science, Universitas Indonesia, Indonesia, 2008.

[3] E. Agustin, Winarto, \& A. Widodo, "Pertimbangan-Pertimbangan Melakukan IT Outsourcing dan Proses Pemilihan Vendor: Suatu Kajian Literatur, ” Jurnal Konferensi Nasional UKWMS kedua, 2008.

[4] B. Rahmad \& Supangkat, "Analisa Perbandingan Framework IT Governance: COBIT, ITIL, COSO, ISO 17799, AS 80152005, ” Jurnal Ilmu Komputer dan Teknologi Informasi, vol. 6, pp. 12-19, 2006.

[5] A. Prasetya \& Z.A Hasibuan, "Penggunaan COBIT dan IT-IL Sebagai Alat Analisa dan COBIT dan IT BSC Sebagai Alat Ukur Kinerja Manajemen TI Perusahaan, " Jurnal Sistem Informasi, vol. 2, pp. 44-48, 2006.

[6] H.A. Swasono, "Penilaian Kematangan Tingkat Keselarasan Strategi Teknologi Informasi Terhadap Strategi Bisnis dengan Metode IT-Balanced ScoreCard \& COBIT 4.1. Maturity Model Studi Kasus: PT. ASTRA OTOPARTS, Tbk," Ph.D Thesis, Magister of Information Technology, Faculty of Computer Science, Universitas Indonesia, Indonesia, 2008.

[7] J. Ward \& J. Peppard, Strategic Planning for Information Systems Third Edition, John Wiley \& Sons LTD, England, 2002.

[8] L.M. Applegate, R.D. Austin, \& F.W. McFarlan, Corporate Information Strategy and Management Seventh Edition Text and Cases, McGraw-Hill Education, New York, 2007.

[9] The IT Governance Institute, Cobit 4.1, Illinois, http://www.isaca.org/KnowledgeCenter/cobit/Documents/COBIT4.pdf, 2007, retrieved January 3, 2010. 